\title{
Životné šance sociálnych aktérov v kontexte spoločenského vývoja na Slovensku - subjektívna dimenzia ${ }^{1}$
}

\author{
Gabriela Lubelcová ${ }^{2}-$ Milan Zeman $^{3}$ \\ Life Chances of Social Actors in the Context of Societal Development in Slovakia - \\ Subjective Dimension. The study focuses on the theme of life chances as an opportunity \\ for a full-fledged life and people's livelihood. The first part of the paper focuses on the main \\ conceptual frameworks of lifestyle chances. On the basis of these, an outline of the basic \\ social mechanisms that decide on the real distribution of the life chances of social actors is \\ formulated. Key are presented: performance-distributive, redistributive, control and sociable \\ mechanisms. The second part of the contribution focuses on the analysis of subjective \\ perceptions of life opportunities through a secondary analysis of selected relevant issues \\ from international ISSP research showing subjective assessment of the possibilities and \\ factors of life success and self-realization of people during the transformation development \\ of Slovak society. \\ Sociológia 2019, Vol. 51 (No. 5: 455-482) \\ https://doi.org/10.31577/sociologia.2019.51.5.20
}

Key words: Life chances; entitlements and provisions; mechanisms of life opportunities distribution; life success and their subjective reflection

\section{Úvod}

Analýzy spoločenského vývoja na Slovensku poukazujú na narastajúce sociálne nerovnosti $\mathrm{v}$ mnohých oblastiach života a fungovania spoločnosti. Sociálny svet l'udí sa diferencuje a ponúka tak odlišné príležitosti pre plnohodnotný život, životné vol'by a sebauplatnenie rôznych sociálnych kategórií obyvatel'stva. Pohl'ad na to, aké sú tieto životné príležitosti pre l'udí je preto významnou výzvou pre preskúmanie. Interpretáciu možností uplatnenia l'udí v spoločenskom priestore umožňuje koncept životných šancí, ktorému by sme chceli venovat' pozornost' $\mathrm{v}$ tejto štúdii. $\mathrm{V}$ prvej časti sa budeme venovat' konceptuálnym rámcom poňatia životných príležitostí a pokúsime sa o identifikáciu ich klúčových mechanizmov v inštitucionálnom usporiadaní spoločnosti, ktoré rozhodujú o reálnej distribúcii životných šancí sociálnych aktérov. Následne sa pokúsime na základe vybraných výskumných zistení identifikovat' vnímanie životných príležitostí sociálnymi aktérmi a ich reflexiu rozhodujúcich determinantov životného úspechu l'udí. Sekundárna analýza tohto subjektívneho vnímania životných šancí v perspektíve spoločenského vývoja na Slovensku bude obsahom druhej časti štúdie.

\footnotetext{
1 Štúdia vznikla ako súčast' riešenia výskumného projektu Vzdelanostné nerovnosti na Slovensku (VEGA 1/0224/19) a výskumného projektu Hodnoty v dynamike spoločenských zmien na Slovensku a v Európe (APVV-15-0653).

2 Korešpondencia: Prof. PhDr. Gabriela Lubelcová, PhD., Katedra sociológie, Filozofická fakulta, Univerzita Komenského, Gondova 2, 81499 Bratislava, Slovensko. E-mail: gabriela.lubelcova@uniba.sk

3 Korešpondencia: Mgr. Milan Zeman, Sociologický ústav SAV, Klemensova 19, 81364 Bratislava, Slovensko. E-mail: milan.zeman@savba.sk
} 


\section{Životné šance - vymedzenie, prístupy}

Životné šance môžeme všeobecne charakterizovat' ako priestor možností (príležitostí) pre sebarealizáciu sociálnych aktérov, naplnenie ich životných ciel'ov, sociálneho vzostupu a kvality života. Chápeme ich pritom najmä ako štrukturálne a inštitucionálne determinovanú pravdepodobnost' dosiahnutia určitého statku alebo inak definovaného žiaduceho stavu (šance uplatnit' sa na trhu práce, dosiahnut' určité vzdelanie, určitý príjem, a pod.).

Životné šance sú ovplyvňované dvoma základnými skutočnost'ami. Na jednej strane sú to spoločenské podmienky, v usporiadaní ktorých sú distribuované príležitosti. Na druhej strane je to schopnost' a kapacita sociálnych aktérov tieto príležitosti využit'. Sociologicky je obzvlášt' zaujímavá spoločenská determinácia životných šancí, ktorá vypovedá o otvorenosti spoločenského priestoru, miery nastavenia inštitucionálnych a štrukturálnych kanálov a bariér pre životné vol'by sociálnych aktérov. Téma životných šancí je preto úzko spojená s témou sociálnej stratifikácie a sociálnej mobility (Sopóci 2014; 2017).

Pre konceptualizáciu témy životných šancí pracujeme s niekol'kými klúčovými teoretickými inšpiráciami. Jedným z prvých autorov, ktorý tento termín do sociologického kontextu uviedol, bol M. Weber. Koncept životných šancí bol dôležitým prvkom jeho teórie tried, statusu a moci. Životné šance sú podl'a neho konzekvenciou sociálneho postavenia l'udí. Pre sociálne postavenie je rozhodujúce triedne postavenie, ktoré odráža pozíciu l'udí v ekonomickom usporiadaní spoločnosti. Sociálnu triedu vymedzil ako súhrn osôb spoločne zdielajúcich jednu alebo viaceré determinanty životných šancí (majetok, životné podmienky, skúsenosti) (Weber 1964). Disponujú teda rovnakými alebo podobnými zdrojmi podmieňujúcimi aj podobnost' ich životných šancí. Do rovnakej sociálnej triedy sú zaradení l'udia, čo majú spoločný kauzálny prvok ovplyvňujúci ich životné šance (Sopóci 2014: 147). A sú to predovšetkým typy šancí na trhu práce, ktoré sú klúčcovou charakteristikou, formujúcou zhodné (či podobné) podmienky osudu jednotlivcov a spoločné záujmy. Z podobnosti ekonomického postavenia jednotlivcov vyplýva podobnost' foriem ich sociálneho konania (ako reakcia na postavenie na trhu práce). Triedy tak odrážajú klúčovú diferenciáciu v životných šanciach l’udí.

Weber navyše odlišoval triedne a statusové postavenie človeka. Zatial' čo triedy vyjadrujú objektívnu stránku spoločenskej diferenciácie (viažu sa na disponibilitu zdrojmi spojenými s ekonomickou stránkou života), statusová diferenciácia odráža subjektívny rozmer sociálneho postavenia (spojený so spôsobom života, prestížou a mocou). Sociálna trieda ovplyvňuje materiálne bohatstvo prostredníctvom ekonomických výhod a nevýhod, s ktorými l'udia vstupujú na trh práce a tovarov, statusová skupina prostredníctvom prestíže 
a moci ovplyvňuje spôsoby získavania rôznych výhod a životných šancí členov jednotlivých statusových skupín (tamže: 148).

Weber tak formuloval základ pre sociologické nazeranie na spoločenskú pozíciu jednotlivca. Týmto základom je väzba na spoločenskú diferenciáciu, ktorej rozhodujúcimi (určujúcimi) líniami sú triedna a statusová príslušnost' človeka, čo zásadným spôsobom štrukturuje spoločnost'. Zároveň zakotvuje pojem životných šancí ako produkt (korelát) tejto sociálnej štrukturácie spoločnosti. Sociálne triedy sa stávajú základom životných šancí v industriálnych a postindustriálnych spoločnostiach (Katrňák 2005).

Do súčasného spoločenskovedného uvažovania priniesol inšpiratívny rámec pre problematiku životných šancí R. Dahrendorf (1979; 1988; 1991), ktorý pokrok v historickom vývoji vidí predovšetkým ako pokrok v oblasti životných šancí. Dahrendorf sa téme a pojmu životných šancí venoval explicitne, a preto jeho koncepciu preberieme osobitne.

Životné šance je podl'a Dahrendorfa potrebné chápat' ako funkciu dvoch determinantov - možností vol'by (options) a väzieb (ligatures) sociálnych aktérov. Možnosti vol'by sú štrukturálne príležitosti rozhodovania, ktoré má aktér k dispozícii pre vol'bu spôsobov sociálneho konania a životných aktivít. Väzby sú určitým druhom záväzku zakotveného v našich hodnotách, vzt'ahoch a významoch, ktoré im pripisujeme. Väzby možno chápat' ako určité puto k významným princípom a dôležitým iným (osobám), ktoré orientujú aktéra v priestore možností volieb a dávajú jeho vol'bám zmysel. Špecifická kombinácia možnosti vol'by a väzby v danom okamihu vytvára šance, ktorými sú determinované životy l’udí v spoločnosti. V závislosti na svojich sociálnych pozíciách a rolách jedinec zastáva svoje miesto v systéme záväzkov, väzieb či pút (Dahrendorf 1979: 30).

Koncepcia životných šancí ako spoločensky podmieneného pol’a možností konania vyjadruje sociálne determinovaný priestor možností volieb individuálneho konania. Možnosti volieb (options) pre individuálne konanie reprezentujú alternatívy, ktoré majú l'udia v sociálnom priestore $\mathrm{k}$ dispozícii. Tieto sú podla Dahrendorfa tvorené systémom oprávnení (entitlements) a zaopatrení (provisions) (Dahrendorf 1991: 54). Oprávnenia označuje Dahrendorf ako vstupenky, kanály prístupu, resp. obmedzení pre možnosti vol'by. V zásade sa vzt’ahujú ku konceptu občianstva a reprezentujú otvorenost' prístupu l'udí k alternatívam, možnostiam volieb konania. Pre využitie otvorených možností volieb konania však aktér potrebuje aj disponovat' prostriedkami na realizáciu týchto možností. Túto kapacitu reálne využit oprávnenia mu sprostredkúvajú zaopatrenia (zdroje, ktorými môže disponovat' - majetok, príjem, vzdelanie, informácie, a pod.). Pozícia jednotlivca v sociálnej štruktúre významne určuje priestor jeho oprávnení a zaopatrení. V inštitucionálne nediskriminujúcom prostredí spoloč- 
nosti sú oprávnenia široko distribuované, ale zaopatrenia (reálne disponibilné zdroje) môžu limitovat' formálne garantované oprávnenia l'udí.

Ak nám systém oprávnení a zaopatrení priamo implikuje pozíciu človeka v sociálnej štruktúre, ktorá významne determinuje spoločenskú distribúciu životných šancí, inšpiratívnym je aj druhá zložka, ovplyvňujúca životné šance, a tou sú väzby a putá (ligatures), ktoré jednotlivca sociálne a kultúrne vzt'ahujú k svojmu spoločenskému kontextu.

Podl'a Dahrendorfa poskytujú tieto väzby významy a orientácie pre naše životné vol'by (väzby a putá k rodine, kolektivite, náboženskému, etickému ideálu, a pod.). Sú oporou, ktorá usmerňuje naše vol’by konania a dáva im zmysel.

Prijatie takéhoto vymedzenia nám umožňuje skúmat' aj subjektívnu stránku životných šancí. Ide o uchopenie významu možností vol'by, ktoré človek sám vníma a reflektuje.

Dahrendorfovo poňatie pokladáme za základné východisko pre interpretáciu životných šancí. Na jednej strane ich formuje spoločensky štrukturovaný priestor prístupu ku zdrojom pre realizáciu životných aktivít, na druhej strane ale ide aj o subjektívne reflektovaný význam týchto životných aktivít. Pri skúmaní životných šancí preto pokladáme za dôležité sústredit’ sa na preskúmanie otvorenosti spoločenského priestoru (objektívne, štrukturálne charakteristiky), ako aj na subjektívne vnímané významy vol'by, ktoré sa prejavujú $\mathrm{v}$ aktivizačnom a mobilizačnom potenciáli sociálnych aktérov.

Životné šance sa teda viažu tak na objektívnu, ako aj subjektívnu dimenziu života l'udí a tematizujú makro i mikro úroveň sociálneho postavenia človeka. Prístupom, ktorý sa pokúša prepojit' tieto dimenzie a ponúka alternatívny interpretačný rámec, je koncepcia P. Bourdieuho (Bourdieu 1984; 1998). Jej základnými pojmami sú habitus, pole a kapitál a ako uvádza samotný autor, ich hlavným spojovníkom je dvojsmerný vzt’ah medzi štruktúrami objektívnymi (štruktúrami sociálneho pol’a) a štruktúrami osvojenými (štruktúrami habitu) (Bourdieu 1998: 7). V našom kontexte by sme mohli sociálne pole interpretovat' ako priestor životných volieb, v ktorom sa realizujú životné praktiky sociálnych aktérov. Toto pole je štrukturované a na aktéra $\mathrm{v}$ ňom pôsobia vonkajšie tlaky (určované štrukturálnymi charakteristikami pola, čo nás nepriamo odkazuje k determinácii priestoru sociálneho pol'a ako možností vol'by pozíciou v sociálnej štruktúre a rôznych osiach/dimenziách sociálnej stratifikácie a diferenciácie), ako aj vnútorné nátlakové sily (interiorizované v procese socializácie človeka, stelesnené v pojme habitus). Habitus reprezentuje systematicky štruktúrované dispozície $\mathrm{k}$ vnímaniu, interpretácii a konaniu v sociálnom poli. Bourdieu ho označuje aj ako socializované telo, ktoré do seba pojalo imanentné štruktúry určitého sveta a štrukturuje podl'a neho spôsob vnímania tohto sveta a konanie v ňom (tamže: 110). Možnosti životných 
praktík (životných volieb) sú determinované týmito vonkajšími a vnútornými tlakmi, ktoré otvárajú, resp. limitujú priestor volieb.

Významným druhom obmedzení $\mathrm{v}$ priestore sociálneho pol’a sú okrem týchto externých a interných obmedzení predovšetkým limity, viažuce sa k zdrojom, ktoré má aktér $\mathrm{k}$ dispozícii a jeho schopnost'ami strategicky ich využit'. Bourdieu tieto zdroje chápe a interpretuje ako kapitály, v rámci ktorých odlišuje niekol'ko základných foriem: ekonomický, sociálny, kultúrny a symbolický. Kapacita týchto kapitálov a spôsoby ich akumulácie ovplyvňuje reálne využitie priestoru volieb sociálneho pol’a človeka.

Uvažovanie o životných šanciach ako o vol'be alternatív v disponibilnom priestore možností vol'by, zdá sa, nás ukotvuje $\mathrm{k}$ tradičným sociologickým dilemám vzt’ahu medzi vonkajškovou (objektívnou) a vnútornou (subjektívnou) podmienenost'ou l'udského konania. V širšom zmysle ide o klasický sociologický problém vzt’ahu štruktúry (vonkajškového spoločenského sveta) a konania (aktéra a jeho intencií). Významné impulzy k reformulácii tohto problému priniesli niektoré prístupy, spojené s tzv. návratom k vel'kej teórie ku koncu 20. storočia. Hoci explicitne tieto prístupy neriešia tému životných šancí, interpretácie sociálneho konania v spoločenskom kontexte nám, hoci nepriamo, môžu o mechanizme životných šancí napovedat'.

Preto sa budeme stručne venovat' niektorým z týchto teoretických prístupov, ktoré pokladáme za potenciálne inšpiratívne pre poňatie životných šancí. Osobitne pôjde o teóriu štrukturácie A. Giddensa a model sociálneho konania J. C. Alexandra ${ }^{4}$.

Giddensova koncepcia je práve pokusom o prekonanie oddel'ovania štruktúry a konania $\mathrm{v}$ tradičných sociologických koncepciách. Toto sociologické rozdelenie (dualizmus) nahrádza Giddens princípom duality (súbežného prepojenia) konania a štruktúry. V jeho koncepcii sociálne štruktúry nie sú mimosubjektová, vonkajšková danost', ale ako súbor pravidiel a zdrojov (tak Giddens vymedzuje sociálne štruktúry) sú neustále produkované a reprodukované aktmi konania vedomých aktérov (Giddens 1984).

Teória štrukturácie je zároveň aj analytickým prepojením medzi makro úrovňou (štruktúrou spoločnosti) a mikroúrovňou (individuálnym konaním). Autor sa v nej pokúsil o syntézu významných teoretických sociologických konceptov: na jednej strane tradície štruktúrneho funkcionalizmu s jeho dôrazom na spoločenský celok, ktorý je vo vzt’ahu k aktérovi dominantný (determinujúci) a na druhej strane interpretatívnych konceptov, ktoré stavajú do popredia konajúcich jednotlivcov, ktorí $\mathrm{v}$ procese sociálnych interakcií permanentne rekonštruujú sociálny svet. Vzt’ah konania a štruktúry $\mathrm{v}$ jeho

\footnotetext{
${ }^{4}$ Nepôjde nám pritom o komplexnú charakteristiku prístupov týchto autorov. Náš výklad je selektívny a zameriava sa iba na tie stránky uvádzaných teoretických prístupov, ktoré pokladáme za inšpiratívne pre uvažovanie o konceptualizácii životných šancí.
} 
poňatí nie je oddelený, nejde o dva nezávislé súbory fenoménov, ale majú skôr komplementárnu povahu, aktéra a štruktúru chápe ako vzájomne sa podmieňujúci a ovplyvňujúci celok v procese vzájomného pôsobenia (dualita). Sociálne štruktúry sú determinantom, ale aj dôsledkom konaní aktérov. Nie sú vonkajškové, ale vstupujú do rozhodovania aktéra ako organizované praktiky sociálneho konania (inštitúcie).

Sociálne štruktúry majú podoby pravidiel alebo zdrojov ${ }^{5}$. Aktér disponujúci znalost'ou pravidiel a prístupom ku zdrojom, napíňa prostredníctvom konania svoje ciele, ktoré sú ale zároveň definované prostredníctvom štruktúr. Konaním aktér súčasne reprodukuje a (re)konštituuje štruktúry. Konanie má zároveň reflexívnu povahu, teda aktér vyhodnocuje vol'bu ciel'ov, prostriedkov aj účinkov konania (Giddens 1984) ${ }^{6}$.

Giddensova koncepcia prezentuje aktéra ako aktívnu a (seba)reflektívnu bytost' so sociálnou spôsobilost'ou fungovat' v spoločenskom rámci ovplyvňovanom sociálnymi štruktúrami, ktorých jadrom sú inštitucionalizované praktiky sociálneho života.

Ak by sme chceli aplikovat', resp. využit' Giddensovu interpretáciu na uvažovanie o konceptualizácii našej témy, mohli by sme uzatvárat', že životné šance sú utvárané aktérovou schopnost'ou „odčítat“" príležitosti v sociálnom a symbolickom usporiadaní spoločnosti (táto jeho schopnost' je určovaná jeho zásobou poznania o sociálnom svete, znalost’ou pravidiel, ustálených praktík, reflexívnych sociálnych kompetencií) a zároveň jeho disponibilitou zdrojmi (resp. mocou disponovat' materiálnymi a nemateriálnymi prostriedkami) na ich uplatnenie pri presadzovaní svojich ciel'ov. Tieto ciele ale nie sú voluntaristicky určované aktérom, ale sú spoluvytvárané sociálnou štruktúrou prostredníctvom rekurzívnych praktík každodenného života. Štruktúra na jednej strane obmedzuje konanie, ale na druhej ho aj umožňuje (Šubrt 2001: 143), teda môžeme povedat', že otvára, ale aj limituje životné príležitosti človeka.

Posun v interpretácii vplyvných fenoménov spoluurčujúcich konanie urobil J. C. Alexander, ktorý vo svojej koncepcii kultúrnej sociológie upriamil pozornost' na kultúru, a to nielen ako vonkajškový, determinujúci fenomén pre sociálne konanie, ale ako relatívne autonómny systém, stojaci $\mathrm{v}$ centre sociálneho sveta človeka, ako aj jeho sociologickej reflexie (preto označenie kultúrna sociológia) ${ }^{7}$.

Alexander vo svojom koncepte konania vychádzal z parsonsovského modelu troch systémov konania: osobnosti, sociálneho systému a kultúrneho

\footnotetext{
5 V poňatí autora sú pravidlá normatívne (legitimizačné procesy a sankcie) a interpretatívne (významy a interpretačné schémy), zdroje vymedzuje ako alokatívne (materiálnej povahy) a autoritatívne (spojené s mocou).

6 Bližšie pozri aj: Sopóci 2013, Šubrt 2001, Šubrt - Balon 2010.

7 Osobitnú pozornost' interpretácii kultúrnej sociológie J. C. Alexandra ako špecifickému modelu vzt’ahu kultúry a konania venoval v pozoruhodnej analytickej práci M. Skovajsa (Skovajsa 2013)
} 
systému. Do popredia však stavia predovšetkým kultúrny systém. Ten chápe ako systémovo usporiadané prostredie konania, ktoré má dve základné funkcie: konštruuje realitu (je teda usporiadaným prostredím konania) a súčasne je prostriedkom hodnotenia reality aktérom (je teda súčastou vnútorného prostredia konania, prostredníctvom kultúrnych kódov a motivačných vzorcov, ktoré si aktéri v priebehu života, najmä v procese socializácie, interiorizujú). Aktér je slobodný v procese vol'by konania, ale zároveň obmedzovaný (a motivovaný) štruktúrami: svojej osobnosti, internalizovanej kultúry a sociálnymi vzt’ahmi (sociálne siete, ktoré aktéri vytvárajú v procesoch vzájomnej interakcie) (Alexander 1988, podl'a Šubrt - Balon 2010).

Interpretačnú (hodnotiacu) úlohu kultúry uplatňuje vo svojom mikrosociologickom modeli konania (Alexander 1982: 301-329). Podl'a neho konanie prebieha $\mathrm{v}$ dvoch dimenziách, ktorými sú interpretácia a strategizácia. Interpretácia sa skladá z dvoch procesov: typizácie a invencie. Typizácia znamená aplikáciu jestvujúcich (a nažitých, resp. socializovaných) kultúrnych klasifikácií a schém, prostredníctvom ktorých chápeme a interpretujeme podnety z prostredia. Pre sociálne fungovanie človeka však nestačí iba prostá reproduktívna typizácia, ale je nevyhnutná aj modifikácia kultúrnych schém, prispôsobenie kultúrnych kódov novým reáliám, čo označuje ako kreatívnu typizáciu. Typizácia tak produkuje aj posuny v klasifikácii a interpretácii, teda invenciu. Vd’aka tomu môžeme konzistentne konat', ale zároveň konaním je produkovaná kultúra, ktorá následne vstupuje do interpretačných rámcov v ret’azení procesov sociálneho konania.

Procesy typizácie a invencie sú primárne kultúrnej povahy. Druhou dimenziou konania je však strategizácia, ktorá vnáša do procesov konania racionálny kalkul a praktický rozmer realizácie aktérových intencií. Tu sú aktéri nútení konat' v súčinnosti alebo opozite k ostaným l'ud'om alebo prostrediu a zobrat' tak do úvahy aj sociálne siete (reprezentujúce sociálny systém modelu konania) (Alexander 1982: 320-329).

Konanie sa tak neodohráva vo vzduchoprázdne, ale v rámci kolektívne štruktúrovaných prostredí, ktoré vytvárajú motivačné vzorce, kultúrne kódy a sociálne siete, tie $\mathrm{v}$ konečnom dôsledku pôsobia ako vonkajšie (resp. ako zvnútornené) tlaky prostredia na konanie a ovplyvňujú aktérovu interpretačnú a strategizačnú kapacitu a orientáciu. Tak je individualizovaný model konania ukotvený do kultúrnych a štruktúrnych rámcov, a to najmä cez sociálne roly, ktoré sa viažu na pozíciu jednotlivca v sociálnom prostredí. Tieto rámce a ich elementy teda utvárajú tak obmedzujúce, ako aj otvárajúce podmienky pre alternatívy konania a zároveň určujú normatívne smerovanie pre akty sociálneho konania (Lubelcová 2014: 186).

${ }^{8}$ Bližšie pozri aj Lubelcová 2014: 185-186. 
Hoci sa terminologicky koncepcie Giddensa a Alexandra líšia akoby dôrazom na iný typ spoločenských rámcov (Giddens hovorí a štruktúre, Alexander o kultúre), viacerí autori (napr. Skovajsa) upozorňuje, že hoci Giddens nepoužíva explicitne termín kultúra, implicitne (a najmä na základe interpretácie samotnej štruktúry, ktorú definuje najmä ako pravidlá (normatívne a interpretačné) a zdroje materiálnej a nemateriálnej povahy) vlastne s fenoménmi kultúrnej povahy pracuje (Skovajsa 2013).

Spoločným rysom je aj snaha o prekonanie oddel'ovania objektívneho sveta (podmienky konania) a subjektívneho sveta (ciele a motívy konania), ktoré sú v týchto novších sociologických koncepciách (pod vplyvom interpretatívnych a interakčných koncepcií) previazané cez proces rozhodovania v procese sociálneho konania. Sociálne konanie sa tak stáva viac reflexívnym (menej jednoducho vonkajškovo determinovaným) procesom, vol'ba jeho alternatív je viac otvorená. Aktér je vnímaný v poli možností vol'by. Je viac svojbytný a volí modality konania, ktoré majú individuálny zmysel. Ten ale nie je oddelený od sociálneho kontextu aktéra. Naopak, zmysluplnost' konania a jeho volieb je daná záväzkami v intersubjektívnom kontexte. Reálny priestor jeho volieb je nad’alej ovplyvňovaný štrukturálne a kultúrne determinovaným pol’om životných šancí pre jeho uplatnenie a sebarealizáciu (Lubelcová 2014: 191).

\section{Náčrt konceptualizácie životných šancí}

Využijúc teoretické inšpirácie sa pokúsime o rámcový náčrt konceptualizácie analytického priestoru životných šancí.

Charakterizovali sme životné šance ako priestor možností (príležitostí) pre sebarealizáciu, sebauplatnenie sociálnych aktérov, napín̆anie ich životných ciel'ov, dosiahnutie sociálneho vzostupu a kvality života.

$\mathrm{V}$ prvom rade sú podmienené spoločenskými podmienkami, v ktorých sú príležitosti distribuované. Tu môže byt' inšpiratívna interpretácia životných šancí ako štruktúrovaného sociálneho pol'a, v ktorom sa realizujú životné praktiky sociálnych aktérov (Bourdieu). Distribúciu životných šancí v spoločenskom priestore môžeme identifikovat' cez otvorenost' spoločnosti. Tá sa prejavuje v distribúcii práv a oprávnení (podl'a Dahrendorfa vstupeniek) dosahovat' životne dôležité zdroje (materiálne, sociálne, kultúrne).

Táto distribúcia prístupov $\mathrm{k}$ významným zdrojom má formálnu a neformálnu rovinu. Formálna rovina reprezentuje právne zabezpečenú rovnost' prístupu, vyjadrenú občianskym statusom človeka v modernej spoločnosti, jeho formálnym vybavením občianskymi právami. Moderný koncept občianstva vybavuje jednotlivca individuálnymi l'udskými právami a formuluje jeho oprávnenia v politickej, ekonomickej i sociálnej oblasti. Zároveň uplatňuje princíp rovnosti občanov pri garantovaní týchto práv. Právne zabezpečená 
rovnost' inštitucionalizovaného prístupu $\mathrm{k}$ jednotlivcovi je doplnená antidiskriminačnou legislatívou, ktorá zdôrazňuje zamedzovanie diskriminačných prístupov (podl'a kolektívnych sociálnych charakteristík, napr. podl’a pohlavia, veku, vierovyznania a pod.) vo verejnej sfére. V neformálnej rovine sa ale môžu diskriminačné prístupy prejavovat' (najmä ako výraz socio-kultúrne podmienených hodnotení $\mathrm{v}$ podobe stereotypov a predsudkov). Tie môžu reálne (aj ked' skrytými praktikami) bránit' formálne otvorenému prístupu ohrozených kategórií (napr. podla pohlavia, veku, etnicity a pod.) k významným zdrojom a príležitostiam.

$\mathrm{V}$ podmienkach nedostatočnosti dôležitých zdrojov (ale aj zníženia inštitucionálnych mechanizmov vymáhania rovnosti prístupu) sa môžu presadzovat' nelegálne, podvodné praktiky (korupcia, nepotizmus, protekcia a pod.), prostredníctvom ktorých sa niektoré štruktúry a jednotlivci dostávajú $\mathrm{k}$ dôležitým zdrojom a iným sú prístupy obmedzované. O týchto alternatívnych cestách prístupu rozhodujú najmä pozície jednotlivcov v rozdelení moci v spoločnosti ${ }^{9}$.

Aby sa oprávnenia mohli transformovat' do životných šancí, potrebujú zaopatrenia, teda cesty, kanály prístupu k príležitostiam (Dahrendorf). Tie sú súčast'ou objektívnej spoločenskej determinácie životných šancí a sú ovplyvňované inštitucionálnym nastavením spoločnosti a mechanizmami aplikácie oprávnení. V nich by sme mohli identifikovat' základné mechanizmy ${ }^{10}$ distribúcie a prístupu k životným šanciam.

Za klúčové mechanizmy pokladáme:

1. výkonovo-distributívny mechanizmus (uplatňovaný cez ekonomický systém a ekonomickú aktivitu aktérov, podl'a ich pozície na trhu práce a pracovnej situácie)

2. redistributívny (solidarizačný) mechanizmus (uplatňovaný cez verejné politiky: ako systém náhradných a doplnkových zdrojov a podporných verejných služieb)

3. kontrolný mechanizmus (uplatňovanie formálnej a neformálnej sociálnej kontroly, na dodržiavanie oprávnení a prístupov $\mathrm{k}$ nim)

4. sociabilitný mechanizmus (sociálne siete aktérov ${ }^{11}$, š́rka a sila sociálnych väzieb, orientácia sociálnych sietí).

Výkonovo-distributivny mechanizmus sa týka ekonomickej oblasti ako klúčovej pre sociálnu pozíciu jednotlivca. V modernej a neskoro modernej spoločnosti je ekonomická aktivita sociálnych aktérov a pozícia v nej roz-

\footnotetext{
9 Tu je možné uplatnit' Bourdieuho koncepciu sociálneho kapitálu, ktorý vd’aka vplyvným známostiam a efektívnej reciprocite pri výmene dôležitých statkov reprodukuje sociálne nerovnosti. Zdroje vplyvu a moci nás odkazujú k pozícii jednotlivca $v$ stratifikačnej štruktúre spoločnosti.

${ }^{10}$ K explanačnej funkcii sociálneho mechanizmu v súčasnej analytickej sociológii pozri bližšie Schenk 2017: 61-69.

11 Sociálne siete používame v sociologickom význame ako sociálne interakcie, vzt’ahy a väzby (blízke poňatiu sociálneho kapitálu), najmä v neformálnej rovine.
} 
hodujúcou platformou pre prístup k dôležitým zdrojom. Výkonovo-distributívny mechanizmus odráža otvorený priestor pre vol'bu ekonomickej aktivity (zamestnanec, podnikatel') a zároveň vyjadruje meritokratické kritérium pre spoločenský vzostup jednotlivca. Inými slovami, ekonomická (pracovná) aktivita je hlavným kanálom prístupu ku zdrojom (príjem, prestíž a pod.), ako aj platformou spoločenskej pozície a priestorom spoločenského vzostupu (sociálna mobilita, vzostup na spoločenskom a stratifikačnom rebríčku). Výkonovo-distributívny mechanizmus zároveň vyjadruje otvorenost' modernej spoločnosti, možnost' uskutočňovat' $\mathrm{v}$ otvorenom priestore podnikatel'ských a pracovných aktivít svoje sebarealizačné aktivity a dosahovat' spoločenský úspech. Je vyjadrením princípu rovnosti životných šancí založených na vlastnom výkone a otvárajúcich možnosti vzostupu, čím oslobodzujú jednotlivca od askriptívnych sociálnych charakteristík (vrodené charakteristiky, sociálny pôvod) a umožňujú vlastnú platformu sebaurčenia a kvality života. Výkonovodistributívny mechanizmus sa realizuje cez otvorený trh práce, distribúciu pracovných a podnikatel'ských príležitostí. Na úrovni sociálnych aktérov sa jeho parametre vzt’ahujú aj na povahu pracovného kontraktu, pracovný príjem a ohodnotenie, stabilitu verzus neistotu pracovnej situácie ${ }^{12}$. Je teda stelesnením nielen otvorenosti príležitostí, ale aj reprodukcie sociálnych nerovností.

Redistributivny (solidarizačný) mechanizmus posilňuje rovnost' prístupu k životným šanciam. Vychádza zo skutočnosti, že nie všetci jednotlivci majú rovnaké štartovacie dráhy pre vol'bu a realizáciu životných šancí a môžu disponovat' obmedzeniami (sociálny pôvod, zdravotný stav a pod.) pre ich výber a naplnenie. Realizuje sa cez verejné politiky, ktoré zabezpečujú prístup občanov k dôležitým predpokladom životných aktivít $\mathrm{v}$ modernej spoločnosti (prístup k zdravotnej starostlivosti, prístup ku vzdelaniu, k sociálnemu zabezpečeniu, podporovanému zamestnávaniu, a pod.). Je kompenzačným mechanizmom k obmedzeniam a limitom výkonovo-distributívneho mechanizmu, ktorý by mal posilňovat' rovnost' prístupu k životným šanciam ohrozeným sociálnym kategóriám ${ }^{13}$. Diferencuje sa podl'a miery redistribúcie a adresnosti kritérií ciel'ových sociálnych kategórií, ktorých sa obzvlášt' týka (hlavnými kritériami sú najmä: životný cyklus, vek, zdravotný stav, sociálna situácia a pod.)

Kontrolný mechanizmus zabezpečuje dodržiavanie pravidiel pre rovnost' prístupu k životným šanciam a spravodlivost' pri ich aplikácii. Uplatňuje sa prostredníctvom formálne inštitucionalizovaného systému spoločnosti (cez verejné inštitúcie a právne normy), ale aj prostredníctvom neformálnej (občianskej) kontroly férového nastavenia tohto inštitucionálneho rámca pre prístup sociálnych aktérov k životným šanciam a spôsobu jeho aplikácie

\footnotetext{
$12 \mathrm{~V}$ poslednom období tematizovanú najmä v problematike prekarizácie práce.

13 Ide o sociálne kategórie ohrozené sociálnou exklúziou, ktorá práve vyjadruje dôsledok zníženej kapacity využit' oprávnenia na základe vylúčenia prístupu k dôležitým zdrojom (bližšie Gerbery - Džambazovič 2011).
} 
v praxi. Najmä stav formálnych kontrolných mechanizmov, ich účinnost' a efektívnost' je indikátorom distribúcie životných šancí pre rôzne skupiny sociálnych aktérov, miery ich reálneho prístupu k formálne garantovaným oprávneniam.

Sociabilitný mechanizmus odráža priestor sociálnych sietí v spoločnosti, ktoré sprostredkujú a ul'ahčujú prístup k životným šanciam. Sú to kanály a zdroje spoločne realizovaných aktivít a praktík pri napíňaní životných potrieb a ciel'ov sociálnych aktérov. Otvorenost' a prestupnost' sociálnych sietí (premost'ujúci sociálny kapitál, dôvera) znižuje transakčné náklady, pomáha pri realizácii životných príležitostí a ozmysl'uje naše životné vol'by (vytvára dôležitý sociálno-mobilizačný potenciál pre výber a napíňanie životných šancí a rozvojových príležitostí).

Uvádzané mechanizmy sa pritom uplatňujú na troch úrovniach:

- makro - celospoločenská (nastavenie trhu práce ako inštitúcie, politika zamestnanosti a jej nástroje - adresnost', ciel'ové skupiny, sociálna politika a jej nástroje, cielové skupiny, právny systém a inštitúcie jeho presadzovania a kontroly dodržiavania)

- mezo - regionálna a lokálna (štruktúra a ponuka pracovných príležitostí, regionálne a lokálne politiky zamestnanosti, regionálne a lokálne politiky sociálnej pomoci (sociálne služby), sociálne siete (partnerstvá), verejná správa)

- mikro - rodina, komunita (sociálne siete, svojpomoc, neformálna sociálna opora a pod.).

Príležitosti (diferencovane distribuované v spoločenskom priestore cez uvádzané mechanizmy) sú objektívnym rámcom pre životné šance. Druhou stránkou je schopnost', ochota a kapacita aktéra tieto príležitosti využit'. Táto kapacita aktéra je ovplyvňovaná jeho potenciálmi, ktoré sú určené najmä:

- socio-ekonomickou pozíciou (sociálno-ekonomický status: príjem, vzdelanie, povolanie, prestíź, ekonomická aktivita, pracovná pozícia a pod.)

- sociálnymi siet’ami (široko poňaté ako rozsah a štruktúra sociálnych vzt'ahov a väzieb, ich homogenita verzus heterogenita, sila a slabost' a pod.)

- hodnotovo-kultúrnymi atribútmi (viery, svetonázor, hodnoty, ašpirácie)

- aktivizmom (schopnosti, úsilie, životný štýl).

Inými slovami, aktér disponuje základnými potenciálmi (ekonomický, sociálny a kultúrny), ktoré pretavuje do životných ciel’ov (volieb) a následného sociálneho konania, čím realizuje svoje životné šance. Výsledkom (a aj indikátorom) realizovaných životných šancí môže byt': sociálna mobilita, životný vzostup, životný štýl, pocit spokojnosti, štastia. 
Životné šance očami sociálnych aktérov (sekundárna analýza vybraných dát medzinárodných výskumov)

Zaujala nás možnost' preskúmat' subjektívnu stránku životných šancí, teda aké je vnímanie distribúcie životných šancí obyvatel’mi Slovenska. Inšpirovali sme sa pritom vel'kými medzinárodnými výskumami, realizovanými aj na Slovensku, zameranými na sociálne nerovnosti a hodnotenie rôznych aspektov života l'ud'mi. Prednost'ou týchto výskumov je reprezentatívnost' a najmä opakovanie modulov, ktoré umožňujú porovnanie v čase, a teda možnost' uvažovania o určitých trendoch $\mathrm{v}$ hodnotení životných podmienok a atribútov životných situácií l'udí. Prirodzene, vzhl'adom na to, že pôjde o sekundárnu analýzu dát, nezodpovedajú sledované stimuly úplne presne nami uvažovaným indikátorom životných šancí. Zároveň sme si vedomí, že ide o výskumy verejnej mienky, teda môžu postihnút' iba subjektívnu dimenziu životných šancí, vnímanie a reflektovanie vybraných charakteristík spoločenských podmienok na Slovensku. Zameriame sa na tie otázky, ktoré umožnia komparáciu a môžu naznačit' trendy vo vývoji spoločenského pozadia ako priestoru formovania pola životných šancí v posledných desat'ročiach.

Uvažovanými vhodnými indikátormi subjektívnej dimenzie životných šancí by mohli byt':

- subjektívne vnímanie sociálnych nerovností

- vnímanie možnosti sociálneho vzostupu a jeho determinantov

- vnímanie možností prístupu k dôležitým zdrojom

- hodnotenie spravodlivosti a férovosti verejného priestoru (stav korupcie, dôvera $\mathrm{k}$ inštitúciám a pod.) a spoločenského usporiadania.

V našej analýze sme sa zamerali na možnosti využitia subjektívneho vnímania sociálnych nerovností, ktoré boli skúmané v reprezentatívnych opakovaných výskumoch ISSP v rokoch 1992, 1999, 2009 a 2016, zhromaždených v Slovenskom archíve sociálnych dát ${ }^{14}$. Súčast'ou modulu Sociálne nerovnosti v prvých troch vlnách boli otázky, ktoré sa týkali možnosti dosiahnutia úspechu a sociálneho vzostupu. Respondentom bolo predložených niekol'ko stimulov a na 5-stupňovej škále mali rozhodnút' o miere ich dôležitosti (podstatné, vel'mi dôležité, dôležité, nie vel'mi dôležité, úplne nedôležité). Viaceré stimuly sa opakovali a umožňujú tak dlhodobejší pohl'ad na vnímania vybraných aspektov životných šancí a nepriamo aj na spoločenský kontext, ktorý ovplyvňoval subjektívne vnímanie životných šancí.

V roku 1992 bol výskum realizovaný ešte v rámci Československa a vzorku za SR tvorilo 423 respondentov. Výskum sa realizoval v čase blížiaceho sa

\footnotetext{
14 Ide o výskumy ISSP - International Social Survey Programme realizované v SR v rokoch 1992, 2001 a 2009, modul Sociálne nerovnosti a ISSP 2016, modul Pracovné orientácie, bližšie $\mathrm{k}$ výskumným programom: http://sasd.sav.sk/sk/vyskumne_programy.php
} 
rozpadu spoločného štátu. Čast' obyvatel'stva, ktorá nebola naklonená rozdeleniu spoločného štátu mala obavy o d’alší osud Slovenska z hl'adiska dodržiavania demokratických princípov a z poklesu životnej úrovne. Navyše $\mathrm{v}$ tom čase na Slovensku rýchlym tempom rástla nezamestnanost' a miera inflácie už bola dvojciferná.

Graf č. 1: Dôležitost' pre úspech (v roku 1992)

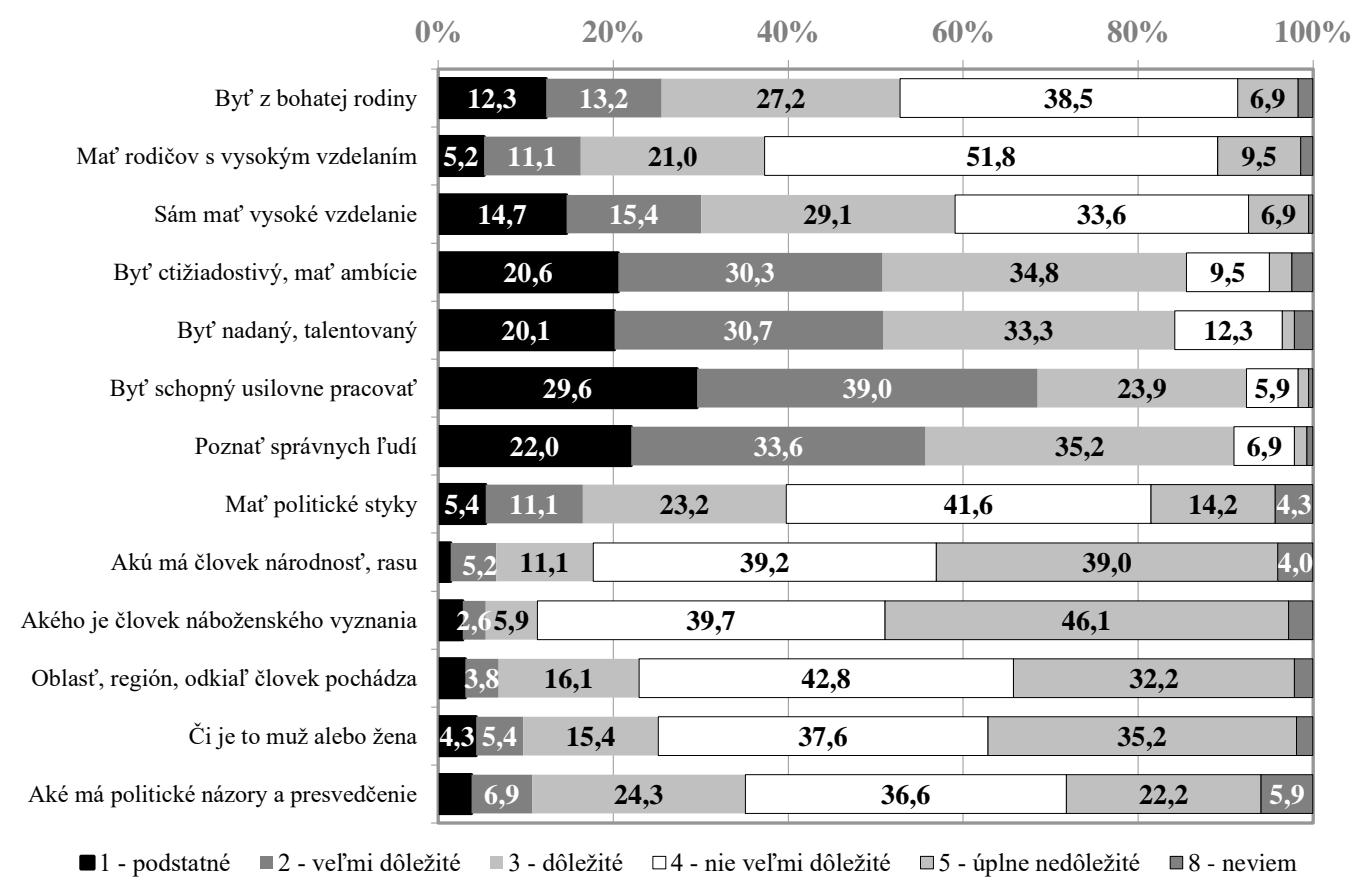

Zdroj: ISSP Sociálne nerovnosti 1992

Respondentom bolo ponúknutých 13 stimulov (bližšie v grafe č. 1), ktoré jednotlivo hodnotili z hl'adiska miery dôležitosti pre dosiahnutie úspechu v živote. Výsledky výskumu ukazujú, že v roku 1992 respondenti najviac považovali za dôležité ${ }^{15}$ pre dosiahnutie úspechu:

- byt' schopný usilovne pracovat' (92,5\%),

- poznat' správnych l’udí $(90,8 \%)$,

- byt' ctižiadostivý, mat' ambície $(85,7 \%)$,

- byt' nadaný, talentovaný $(84,1 \%)$, 15 Údaje získané zrátaním odpovedí hodnotiacich stimuly ako dôležité, t. j. variantov: 1. podstatné, 2. vel'mi dôležité a
3. dôležité. 
- sám mat' vysoké vzdelanie $(59,2 \%)$,

- byt' z bohatej rodiny $(52,7 \%)$.

Naproti tomu respondenti nepovažovali za dôležité (4. nie vel'mi dôležité + 5. úplne nedôležité) pre dosiahnutie úspechu:

- akého je človek náboženského vyznania $(85,8 \%)$,

- akú má človek národnost', rasu (78,2 \%),

- oblast', región, odkial' človek pochádza $(75,0 \%)$,

- či je to muž alebo žena (72,8 \%),

- mat' rodičov s vysokým vzdelaním $(61,3 \%)$,

- aké má politické názory a presvedčenie $(58,8 \%)$,

- mat' politické styky $(55,8 \%)$.

Vo výsledkoch výskumu z roku 1992 sa do určitej miery už prejavuje v tom čase mediálne populárny meritokratický model, v ktorom výkonové faktory jednotlivca (úsilie, aktivita, ctižiadost', vysoké pracovné nasadenie, schopnosti) hrajú ovel'a dôležitejšiu úlohu ako askriptívne charakteristiky (pohlavie, vek, národnost' alebo rasa, náboženské vyznanie).

Vo výskume ISSP Sociálne nerovnosti 1999 sa zopakovali len dva stimuly, ktoré sú dôležité pre úspech -1 . pochádzat' z bohatej rodiny a 2. poznat' správnych l'udí.

\begin{tabular}{lllllll}
\hline & $\mathbf{1}$ & $\mathbf{2}$ & $\mathbf{3}$ & $\mathbf{4}$ & $\mathbf{5}$ & $\mathbf{6}$ \\
\hline 1. pochádzat' z bohatej rodiny & 22,1 & 24,8 & 27,9 & 16,9 & 7,9 & 0,5 \\
2. poznat' správnych l'udí & 30,4 & 44,0 & 20,0 & 3,3 & 1,5 & 0,7 \\
\hline
\end{tabular}

$(1$ = podstatné, $2=$ vel'mi dôležité, $3=$ skôr dôležité, $4=$ nie vel'mi dôležité, 5 = vôbec nie dôležité, $6=$ neviem posúdit')

V porovnaní s rokom 1992 na začiatku spoločenskej transformácie, priebeh transformačného procesu (rok 1999) posilňoval v hodnotení l'udí dôležitost' vysokého významu vplyvných sociálnych sietí (z 90,8 \% na 94,4 \%) a výrazne vzrástlo aj hodnotenie významu materiálnej úrovne pôvodnej rodiny (z 52,7 \% na $74,8 \%$ ).

V rokoch 2009 - 2010 bol realizovaný d’alší výskum ISSP, ktorý v module sociálnych nerovností pri hodnotení dôležitosti pre úspech použil podobné stimuly ako v roku 1992. 
Graf č. 2: Dôležitost’ pre úspech (v roku 2009)

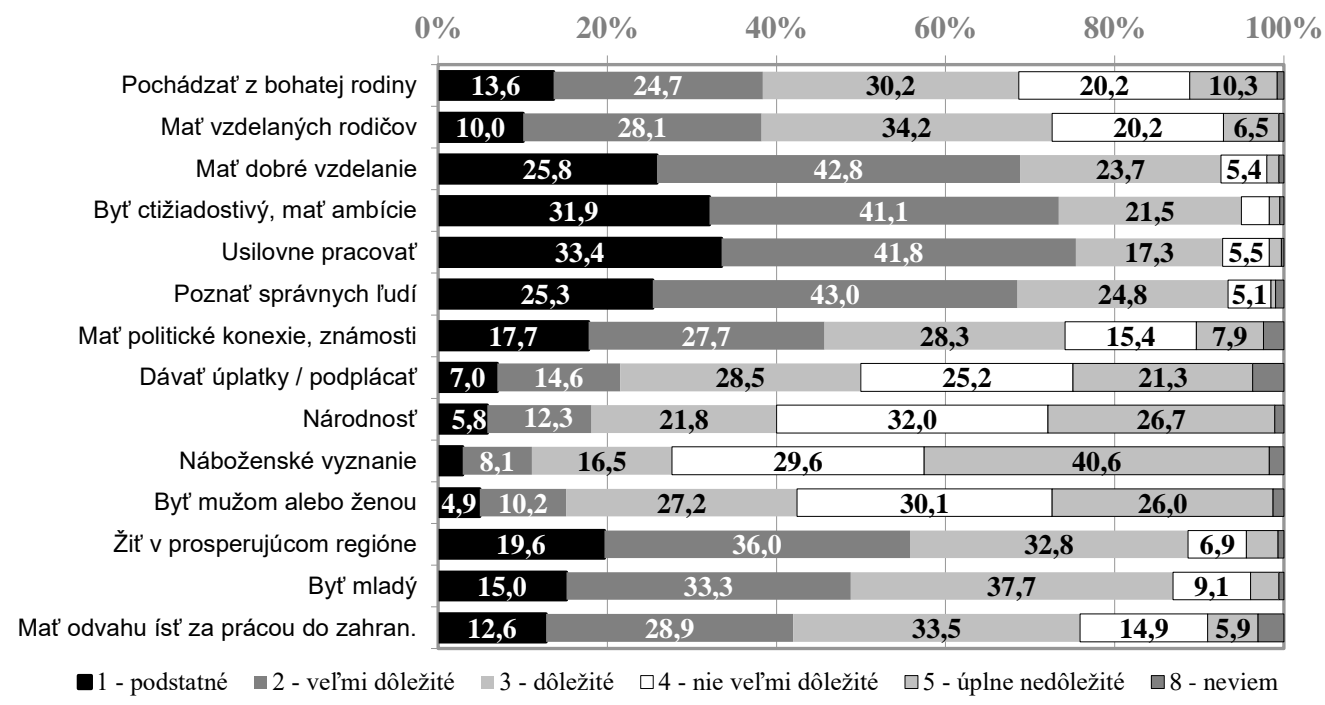

Zdroj: ISSP Sociálne nerovnosti 2009

Výsledky výskumu ukazujú, že v roku 2009 respondenti najviac považovali za dôležité (1. podstatné +2 . vel'mi dôležité +3 . dôležité) pre dosiahnutie úspechu:

- byt' ctižiadostivý, mat' ambície $(94,5 \%)$,

- poznat' správnych l’udí $(93,1 \%)$,

- byt' schopný usilovne pracovat' $(92,5 \%)$,

- mat' dobré vzdelanie $(92,3 \%)$,

- žit' v prosperujúcom regióne $(88,4 \%)$,

- byt' mladý (86,0\%),

- mat' odvahu íst' za prácou do zahraničia $(75,0 \%)$,

- mat' vzdelaných rodičov $(72,3 \%)$,

- byt' z bohatej rodiny $(68,5 \%)$.

Naproti tomu v roku 2009 respondenti nepovažovali za dôležité (4. nie vel'mi dôležité +5 . úplne nedôležité) pre dosiahnutie úspechu:

- náboženské vyznanie (70,2\%),

- akú má človek národnost', rasu $(58,7 \%)$,

- či je to muž alebo žena $(56,1 \%)$,

- dávat' úplatky / podplácat' $(46,5 \%)$.

Na základe porovnania vybraných atribútov, ktoré sú dôležité pre úspech, je možné konštatovat', že medzi rokmi 1992 a 2009 došlo v takmer všetkých 
dôležitých stimuloch $\mathrm{k}$ určitému nárastu. $\mathrm{K}$ žiadnej zmene nedošlo pri stimule „usilovne pracovat"،, ktorý stabilne považovala za dôležitý výrazná väčšina opýtaných $(92,5 \%)$.

V dimenzii sociálneho kapitálu (poznat' správnych l'udí), ktorý považovali za dôležitý takmer všetci respondenti, došlo $\mathrm{k}$ minimálnemu nárastu o 2,3 percentuálneho bodu na 93,1\%.

Graf č. 3: Dôležitost' pre úspech $(1988,1993,2009)$

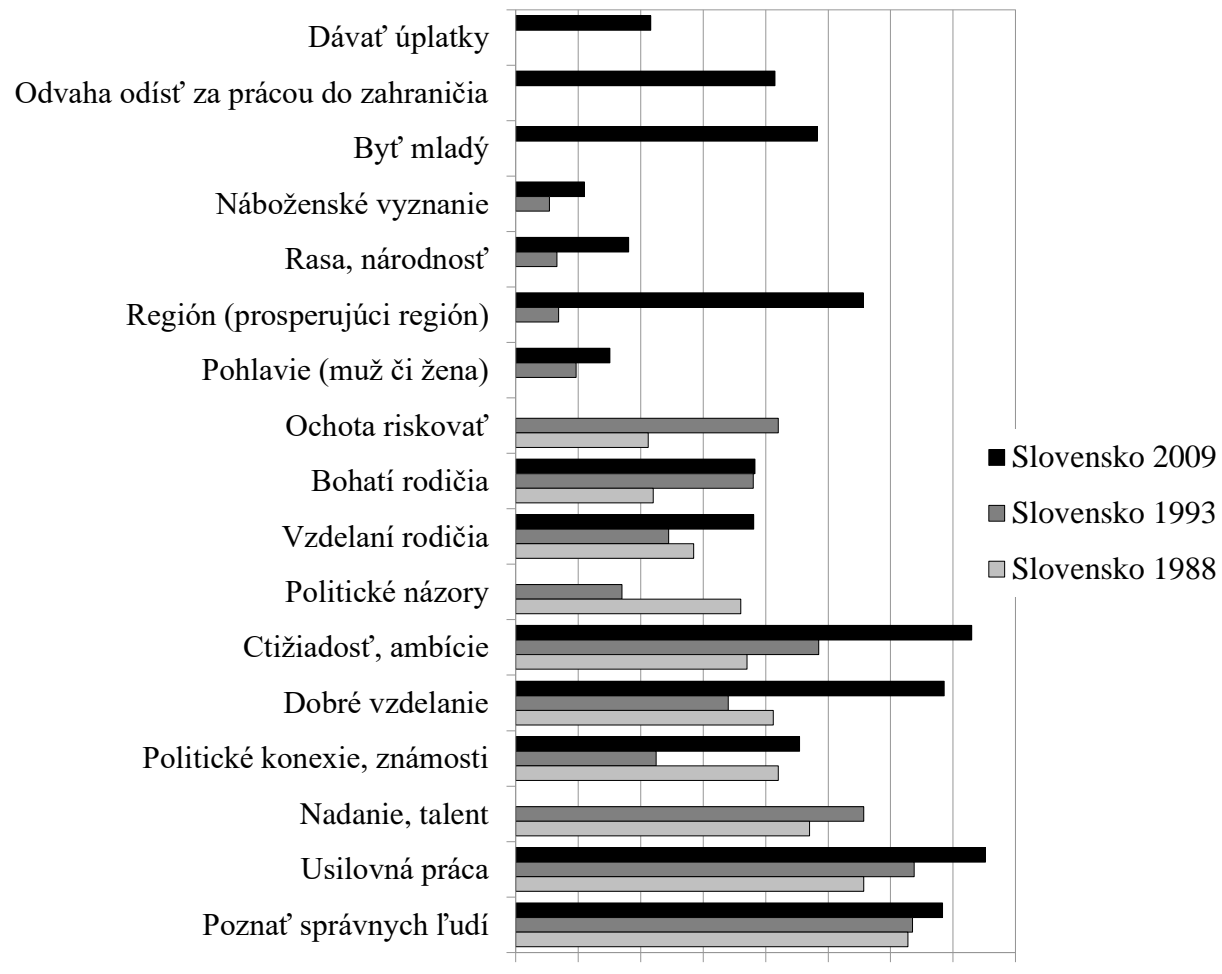

$0 \% 10 \% 20 \% 30 \% 40 \% 50 \% 60 \% 70 \% 80 \%$

Zdroj: Sociálna stratifikácia vo východnej Európe po roku $1989^{16}$, ISSP Sociálne nerovnosti 1992, $2009^{17}$

Mimoriadne vysoký nárast, dokonca najvyšší zo všetkých vybraných stimulov, o 65,4 percentuálnych bodov sme zaznamenali pri stimule „žit' v prosperujúcom regióne“, ktorý pokladá za dôležitý pre dosiahnutie úspechu 88,4 \%

\footnotetext{
16 Odkaz na výskum v archíve SASD: http://sasd.sav.sk/sk/data_katalog_abs.php?id=sasd_1993001. K výsledkom výskumu pozri bližšie: Bunčák - Džambazovič - Sopóci 2013.

17 Graf č. 3 - porovnanie vývoja hodnotenia skutočností dôležitých pre úspech, vychádza z nepublikovanej prezentácie Romana Džambazoviča, autorovi vyjadrujeme pod'akovanie za sprístupnenie.
} 
opýtaných. Táto skutočnost' dokladá silný dopad závažného socio-ekonomického problému Slovenska - regionálnych diferencií a dokonca prehlbovania regionálnych disparít, aj do subjektívneho vnímania determinácie životných šancí regionálnou pozíciou. Druhý najvyšší nárast o 33,1 percentuálnych bodov na $92,3 \%$ sme zaznamenali pri stimule „mat' dobré vzdelanie“, čo nepriamo poukazuje na zmeny na trhu práce a nových preferencií profesiových orientácií.

$\mathrm{V}$ prípade niektorých stimulov je možné sledovat' zmeny v subjektívnom hodnotení dosahovania úspechu práve aj na pozadí zmien spoločenského kontextu (ešte pred rokom 1989) a nepriamo identifikovat' vývoj otvorenosti a férovosti životných šancí l’udí. Predchádzajúci graf č. 3 znázorn̆uje hodnotenie podstatných a vel'mi dôležitých skutočností pre dosiahnutie úspechu v živote v porovnaní rokov 1988,1993 a 2009.

Môžeme si všimnút', že z charakteristík, ktorých je človek nositel'om, sa objektívne pokladajú za menej významné v porovnaní s výkonovými. Rastie význam ctižiadosti, usilovnej práce a dobrého vzdelania pre dosiahnutie životného úspechu, čo môžeme hodnotit’ ako zvyšovanie významu meritokratických kritérií, ale aj vlastných volieb pre životný úspech (napr. odvaha odíst' za prácou). Táto tendencia sa prejavuje aj v porovnaní s obdobím socializmu, v ktorom význam usilovnej práce, nadania a ambícií sa síce tiež oceňoval, ale nie tak výrazne ako $\mathrm{v}$ potransformačnom období. Zároveň sa udržiava významná úloha vplyvných sociálnych sietí a politických konexií, ktoré sa hodnotili ako dôležité nielen v minulosti, ale aj v súčasnom usporiadaní. Význam meritokratických kritérií zrejme súvisí s nielen subjektívnym hodnotením ich významu pre úspech, ale aj celkového tlaku na výkon (na čo nepriamo poukazuje rast hodnotenia mladosti a odvahy odíst' za prácou) a diferencovanej distribúcie príležitostí (výrazný nárast významu regiónu). Môžeme uzatvárat, že síce rastie význam výkonových parametrov (čo by mohlo signalizovat' väčšiu závislost' životných šancí od individuálneho nasadenia a nepriamo aj otvorenost' prístupu k životným šanciam), ale meritokratické princípy sa skôr presadzujú ako zmeny hodnotovej klímy na pozadí spoločenskej transformácie (prechod na trhovú ekonomiku) a signalizujú skôr obmedzovanie životných šancí v slovenských podmienkach (potreba odvahy odíst' za prácou do zahraničia) a prehlbovanie ich diferenciácie v spoločenskom priestore na Slovensku (rast významu regiónu), ako rast otvorenosti prístupu k životným šanciam u nás. Zároveň zostáva vysoká úroveň hodnotenia závislosti prístupu $\mathrm{k}$ životným šanciam prostredníctvom vplyvného sociálneho kapitálu jednotlivcov (čo signalizuje skôr deformáciu výkonovo meritokratického mechanizmu distribúcie životných šancí na Slovensku).

To preukazuje aj celkové hodnotenie rovnosti životných šancí (graf č. 4), o ktorej je presvedčených iba zhruba $1 / 3$ respondentov. Naopak, asi $1 / 3$ 
nehodnotí životné šance ako rovnaké a takmer $1 / 3$ má k téme ambivalentný vzt'ah.

\section{Graf č. 4: Na Slovensku majú všetci rovnaké šance dosiahnut' v živote úspech}

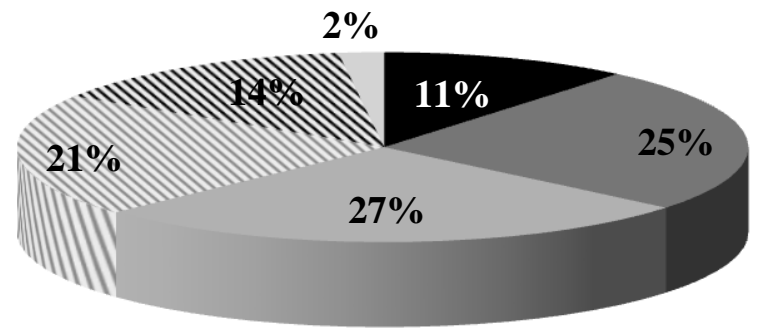

$$
\begin{aligned}
& \text { —úplne súhlasím } \\
& \text { nkôr súhlasím } \\
& \text { ani súhlasím, ani } \\
& \text { nesúhlasím } \\
& \text { vkôr nesúhlasím } \\
& \text { •vôbec nesúhlasím } \\
& \text { nevie / neodpovedal }
\end{aligned}
$$

Zdroj: ISSP Sociálne nerovnosti 2009

V hodnotení respondentov sú podl'a výskumov významným sprostredkujúcim faktorom pre prístup $\mathrm{k}$ dôležitým zdrojom a životnému úspechu vplyvné známosti. Ukazuje sa teda, že individuálny sociálny kapitál je hodnotený ako dôležitý sprostredkujúci kanál, čo naznačuje limitnú otvorenost' a rovnost' prístupu k životným šanciam v našej spoločnosti. Zároveň môžeme konštatovat' ambivalentnú, až protikladnú pozíciu (a pôsobenie) individuálneho a kolektívneho sociálneho kapitálu.

V medzinárodných výskumoch sa ako indikátor kolektívneho sociálneho kapitálu často používa meranie dôvery v zmysle korelátu skúsenosti zo vzájomného pôsobenia a vzájomných vzt'ahov medzi sociálnymi subjektmi. Dôvera ako kolektívny (zdiel'aný) sociálny statok sa interpretuje v podobe sociálneho kapitálu, nakol'ko ul'ahčuje interakciu, vytvára podporné a partnerské sociálne prostredie a znižuje tak náklady pri presadzovaní životných volieb l'udí. Výsledky výskumov dôvery v slovenskom prostredí ${ }^{18}$ však poukazujú na nízku úroveň interpersonálnej dôvery a osobitne nízku úroveň dôvery $\mathrm{k}$ dôležitým inštitúciám, ktoré reprezentujú a mali by garantovat' otvorený a rovnocenný (spravodlivý) prístup l'udí k dôležitým zdrojom. Nízka úroveň dôvery limituje sociálno-mobilizačný potenciál slovenskej spoločnosti, kooperativitu a partnerstvo pri presadzovaní spoločne zdiel'aných záujmov a obmedzuje tak priestor

\footnotetext{
18 Ide najmä o výskumy ISSP Slovensko 2008, EVS 2008 (European Values Study), ESS 2012 (European Social Survey), CSES a ISSP 2016.
} 
formovania životných šancí ( $\mathrm{v}$ podobe samoorganizačných potenciálov využitel'ných v rozvojových programoch najmä na lokálnej úrovni).

Ako nepriamy indikátor otvorenosti a spravodlivosti slovenskej spoločnosti môžeme využit aj otázky dotýkajúce sa názorov na existujúce a žiaduce rozvrstvenie slovenskej spoločnosti ${ }^{19}$. Respondentom tu boli predložené grafické znázornenia typov sociálneho rozvrstvenia a mali jednak zhodnotit', ktorý typ podl'a ich názoru najlepšie vystihuje slovenskú spoločnost' a zároveň ktorý model usporiadania by uprednostnili.

Poskytnuté na hodnotenie boli typy:

Typ E: Vel’a l'udí blízko vrcholu a len málo v blízkosti spodku spoločnosti.

Typ D: Spoločnost's väčšinou l'udí uprostred.

Typ C: Pyramída, ale s vel'mi malým počtom l'udí na úplnom spodku spoločnosti.

Typ B: Spoločnost' ako pyramída, s malou elitou na vrchole, s viacerými l'ud'mi v strede a väčšinou na spodku spoločnosti.

Typ A: Malá elita na vrchole, vel'mi málo l'udí v strede a vel'ké množstvo l'udí na spodku spoločnosti.

Graf (č. 5) zachytáva vývoj názorov na jestvujúci typ rozvrstvenia slovenskej spoločnosti:

Graf č. 5: Existujúci typ rozvrstvenia spoločnosti

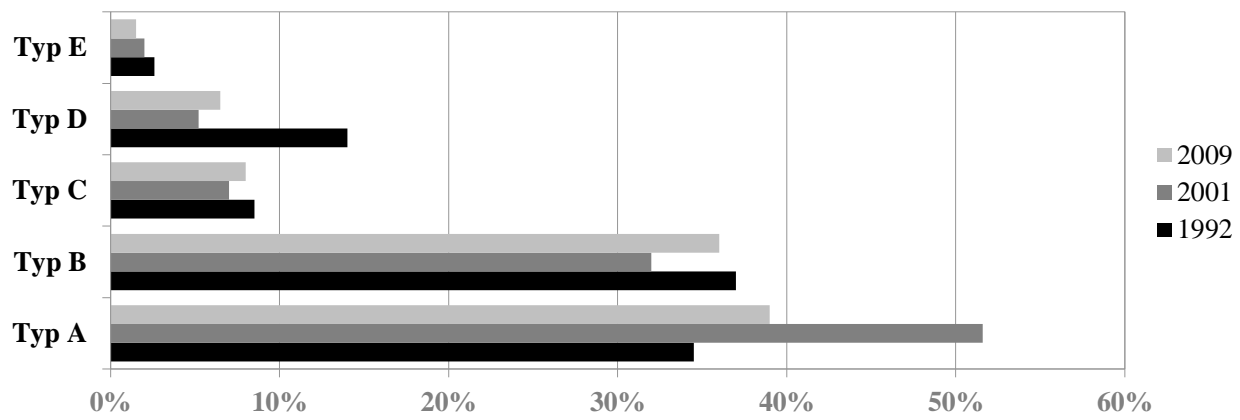

Zdroj: ISSP Sociálne nerovnosti 1992, 2001 a 2009

Respondenti za typické pre slovenskú spoločnost' považovali modely usporiadania s malou elitou na vrchole a väčšinou l'udí na spodku spoločnosti (typ A a B), čo odráža väčšinový názor občanov o nerovnomernom vývoji sociálnej stratifikácie na Slovensku, v ktorom väčšina l’udí nezažíva spoločenský vzostup. Ide teda o značne pesimistický názor l'udí o možnostiach spoločenského vzostupu a otvorenosti životných šancí pre väčšinu l'udí. Ako priaznivý

${ }^{19}$ Výskumy ISSP v rokoch 1992, 2001 a 2009. 
možno hodnotit' posun k rovnomernejšiemu rozloženiu (typ B) v pokročilejšej etape transformácie spoločnosti (rok 2009 oproti roku 2001).

Kritický pohl'ad na rozvrstvenie slovenskej spoločnosti dokladujú aj názory respondentov na žiaduci model. Ich názory a ich vývoj v čase ukazuje graf č. 6:

Graf č. 6: Preferovaný typ rozvrstvenia spoločnosti

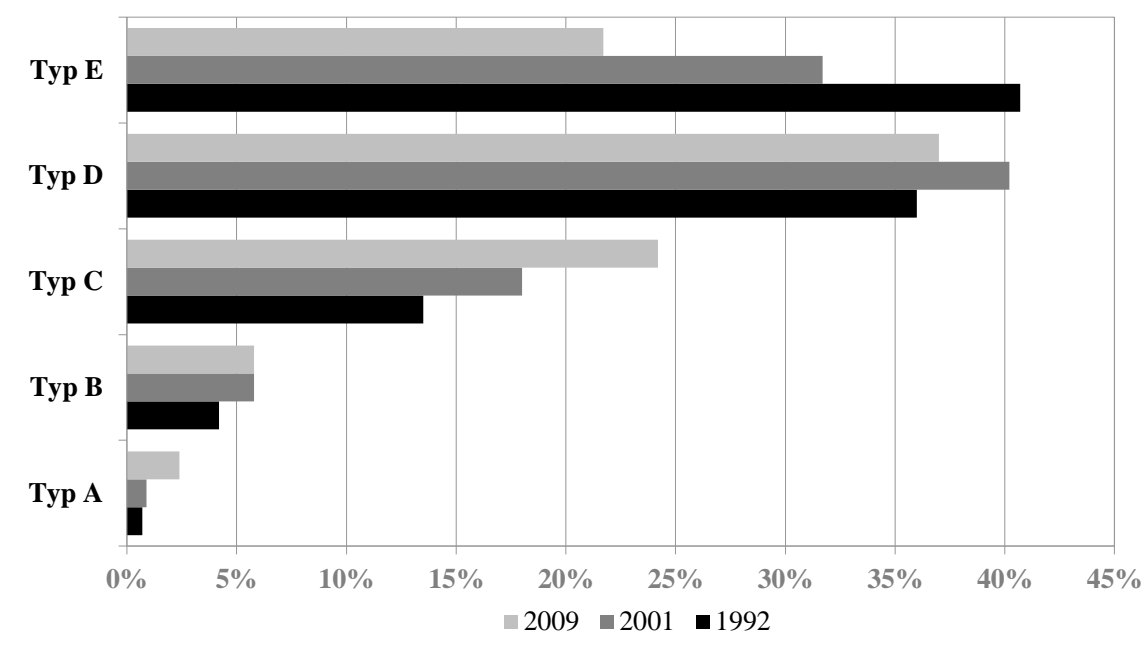

Zdroj: ISSP Sociálne nerovnosti 1992, 2001 a 2009

Protikladnost' hodnotenia reálnej a žiaducej sociálnej štrukturácie spoločnosti je evidentná: usporiadania, ktoré sú pokladané za reálny obraz spoločenského rozvrstvenia, sú najmenej preferované a naopak: žiaduci typ rozvrstvenia je najviac vzdialený tomu, čo si o realite slovenskej spoločnosti respondenti myslia. Vo vývoji preferencií v priebehu transformácie si ale môžeme všimnút', že idealistické očakávanie o masovom vzostupe na začiatku transformácie (preferencia typu E v roku 1992) sa v priebehu času (v roku 2009) zreálnila aspoň do preferencie typu D (spoločnost's väčšinou l'udí uprostred). Žiaducim však zostáva očakávanie malého množstva l'udí v spodnej časti rozvrstvenia.

Pre porovnanie vývoja subjektívneho hodnotenia faktorov významných pre úspech máme k dispozícii aj ostatný medzinárodný výskum ISSP (2016). Zameriaval sa síce na pracovné orientácie, ale opakovala sa v ňom aj vyššie uvedená otázka na životný úspech (na rovnakej škále hodnotenia). Vd’aka tomu môžeme odpovede respondentov porovnat' $\mathrm{v}$ časovom rozmedzí takmer štvrt'storočia $(1992,2009,2016)$, čo ukazuje graf č. 7. 
Graf č. 7: Dôležitost' pre úspech $(1992,2009,2016)$

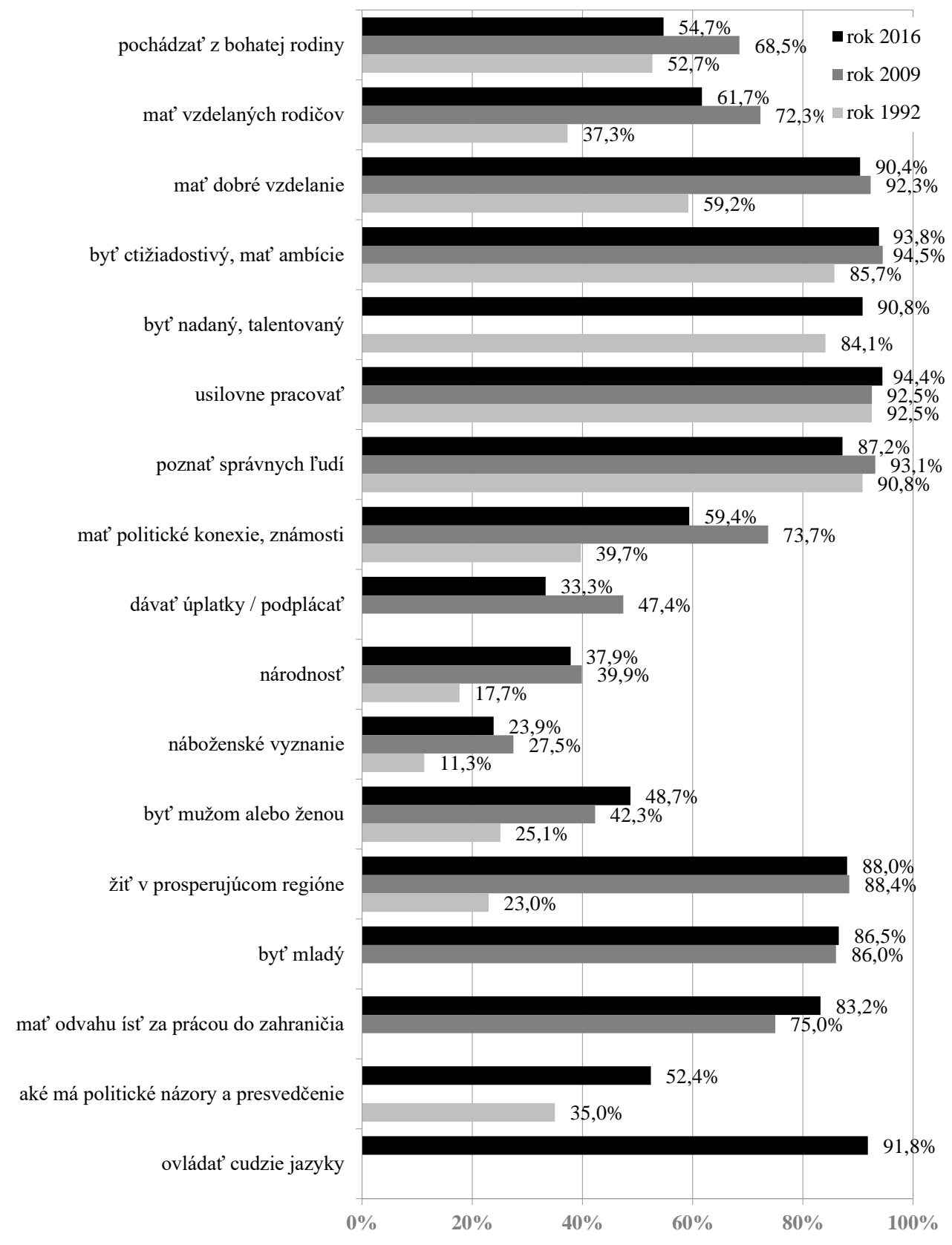

Sociológia 51, 2019, č. 5 
V prvom rade si všimneme najvýraznejšie rozdiely z porovnania rokov 2009 a 2016.

Na základe porovnania vybraných atribútov, ktoré sú dôležité (1. podstatné +2 . vel'mi dôležité +3 . skôr dôležité) pre úspech je možné konštatovat', že v roku 2016 v porovnaní s rokom 2009 došlo k nárastu v týchto štyroch prípadoch:

- mat' odvahu íst' za prácou do zahraničia ( $+8,2$ percentuálneho bodu)

- byt' mužom alebo ženou ( $+6,4$ p. b.),

- usilovne pracovat' $(+1,9$ p. b.),

- byt' mladý ( $+0,5$ p. b.).

V prípade posledných dvoch atribútov je nárast zanedbatel'ný (na úrovni štatistickej chyby). Mat' odvahu íst' za prácou do zahraničia považuje za dôležité $83,2 \%$ opýtaných a nárast o 8,2 perc. bodu naznačuje, že vyššie šance na dosiahnutie úspechu spájajú respondenti s pôsobením za hranicami Slovenska $^{20}$.

Rodový aspekt z hl'adiska dosiahnutie úspechu (byt' mužom alebo ženou) považuje za dôležitý takmer polovica respondentov (48,7\%) a nárast o 6,4 perc. bodu naznačuje mierne posilnenie.

Naopak k poklesu dôležitosti medzi rokmi 2009 a 2016 došlo u týchto atribútov:

- mat' politické konexie, známosti (-14,3 perc. bodu),

- dávat' úplatky / podplácat' (-14,1 p. b.),

- pochádzat' z bohatej rodiny (-13,8 p. b),

- mat' vzdelaných rodičov (-10,6 p. b.),

- poznat'správnych l'udí (-5,9 p. b.),

- náboženské vyznanie (-3,9 p. b.).

Najvyšší pokles nastal u atribútov - mat' politické konexie, známosti $(-14,3$ perc. bodu) a dávat' úplatky / podplácat' (-14,1 p.b.), čo môže viest' $\mathrm{k}$ miernemu optimizmu, že vnímanie klientelizmu a korupcie má klesajúcu tendenciu ${ }^{21}$.

Ak sa pozrieme na celkovú charakteristiku hodnotenia atribútov úspechu v slovenskej populácii v 25-ročnom priebehu, môžeme konštatovat', že za najvýznamnejšie l'udia pokladajú vlastné individuálne (čiastočne výkonové) charakteristiky: usilovná práca, vlastné ambície, talent a dobré vzdelanie sú pokladané za najdôležitejšie, a to relatívne stabilne. Do istej miery sa teda potvrdzuje presadzovanie meritokratickej predstavy životného úspechu, čo je priaznivý výsledok. Relatívne vysokú úroveň si ale udržiava aj hodnotenie

\footnotetext{
${ }^{20}$ Vyššie subjektívne hodnotenie príležitostí pre životný úspech za hranicami korešponduje s objektívnymi migračnými tendenciami a rastom odlivu najmä mladých mozgov za príležitost’ami v zahraničí v sledovanom období. To reprezentuje rizikový fenomén pre budúci rozvoj Slovenska.

21 Podl'a výsledkov hodnotenia stavu korupcie vo výskume ISSP 2016, udržuje sa relatívne vysoké negatívne hodnotenie skorumpovanosti politikov a úradníkov, ale na druhej strane je osobná skúsenost's korupciou zriedkavejšia ako v minulosti (bližšie: Bahna - Zagrapan 2017)
} 
významu kontaktov na správnych l’udí. To naznačuje, že neformálny sociálny kapitál (v bourdieuovskom negatívnom význame) sa v slovenskom prostredí udržiava ako významný kanál prístupu k úspešným životným trajektóriám (a teda v konečnom dôsledku aj mechanizmom reprodukcie sociálnych nerovností). To na jednej strane signalizuje stály modernistický deficit $\mathrm{v}$ inštitucionálnom usporiadaní slovenskej spoločnosti ${ }^{22}$, ktoré by malo zabezpečovat' rovnost' zaobchádzania a prístupu, resp. nedostatočnost' kontrolných mechanizmov fungovania (najmä) verejných inštitúcií. To môže znamenat' neformálne vnímanie pokrivovania oficiálne rovných životných príležitostí, ktoré l'udia reflektujú aj na pozadí relatívne vysokej úrovne vnímania korupcie a nekalých praktík $^{23}$. Zároveň môže signalizovat’ udržiavanie kultúrneho vzoru, podporujúceho také neformálne deformácie prístupov $\mathrm{k}$ významným statkom. Určitým pozitívom je mierny pokles hodnotenia významu tohto faktora v posledných rokoch (hoci iba o 5 percentuálnych bodov). Ak k tomu pripojíme aj pozitívny trend poklesu hodnotenia významu politických konexií a dávania úplatkov, ktorý je v roku 2016 už výrazne nižší ako v predchádzajúcom období, môžeme konštatovat' posilnenie vnímania významu meritokratických charakteristík životného uplatnenia ${ }^{24}$.

Posilnené vnímanie orientácie na výkon v súčasnej spoločnosti nepriamo dokladuje aj pozitívne hodnotenie mladosti ako zdroja (či podmienky životného úspechu). V tomto prípade ale môže znamenat' ambivalentnost' hodnotenia - kto mladý nie je, má horšie vyhliadky na úspech (vnímanie vekovej diferenciácie možností úspechu). Ako spoločensky alarmujúce môžeme hodnotit' výrazný nástup hodnotenia významu regiónu, v ktorom l’udia žijú - je to jasný doklad vysokej a neustále sa prehlbujúcej regionálnej diferenciácie Slovenska a urgentnej potreby posilňovania životných príležitostí v mimobratislavskom okruhu. Fenomén vnímania obmedzených možností doma sa prejavuje aj $\mathrm{v}$ náraste významu odvahy odíst' za prácou do zahraničia.

Individuálne-výkonový príklon $\mathrm{k}$ vnímaniu životných šancí sa prejavuje aj $\mathrm{v}$ určitom poklese hodnotenia významu východiskovej rodiny, a to tak jej ekonomického, ako aj kultúrneho kapitálu, hoci si vnímanie dôležitosti pôvodu ako východiska pre životný úspech jednotlivca stále udržiava relatívne vysoké hodnotenie.

Pri hodnotení určitého diskriminačného potenciálu socio-demografických charakteristík jednotlivcov môžeme konštatovat', že ich vplyvu pre životný

\footnotetext{
22 Máme na mysli univerzalizmus a neosobnost' inštitucionálneho usporiadania ako jedny z hlavných atribútov modernizácie spoločnosti, ktoré reprezentujú rovnost’ prístupov k oprávneniam.

${ }^{23}$ K fenoménu korupcie u nás, bližšie Džambazovič 2015.

24 Je otázkou, ako by tieto hodnotenia nekalých praktík vo verejnom priestore vyzneli v roku 2018, v ktorom Slovensko zažilo niekol'ko dramatických káuz, vedúcich nielen k občianskemu aktivizmu, ale dá sa predpokladat', že aj k rastu kritických hodnotení l'udí vo verejnej mienke.
} 
úspech pripisujú respondenti výrazne nižšiu váhu, oproti predchádzajúcim uvádzaným stimulom. Aj tak však možno spomenút', že viac ako $1 / 3$ pripisuje význam správnej národnosti a najmä výraznejšie rastie hodnotenie významu pohlavia (význam pohlavia zaznamenal v porovnaní rokov 2009 a 2016 druhý najvyšší nárast). Byt' mužom alebo ženou považujú pre diferenciáciu životného úspechu za dôležitejšie o niečo viac ženy (51 \%) ako muži (46 \%), ale relatívne blízke vnímanie dôležitosti tejto skutočnosti u oboch pohlaví vypovedá o závažnosti reflektovania tohto vplyvu (a nepriamo vypovedá aj o miere rodových nerovností na úkor žien). Naznačuje to teda, že presadzovanie rodovej rovnosti má u nás ešte značné rezervy a potreba venovat' jej osobitnú pozornost' skôr spoločensky narastá.

V doteraz prezentovanej sekundárnej analýze sme sa snažili využit' dáta na postihnutie trendov v subjektívnom vnímaní príležitostí pre úspech ako nepriameho indikátora vnímania životných šancí v časovom horizonte troch vín medzinárodných výskumov, postihujúce 25-ročné obdobie. Ostatnú vlnu výskumných zist'ovaní (ISSP 2016) sme sa pokúsili využit' aj na spracovanie diferenciácie vnímania životných príležitostí, a to v dvoch smeroch. Jednak sme sa pokúsili stimuly predkladané respondentom na hodnotenie dôležitosti pre životný úspech spojit' do kvázi typológie orientácie ich preferencií. Následne sme sa zamerali na otestovanie štatistickej významnosti rozdielov ich distribúcie medzi vybranými sociálnymi kategóriami respondentov ${ }^{25}$.

$\mathrm{Z}$ batérie stimulov predkladaných respondentom sme sa pokúsili vytvorit' kvázi typológiu pripisovaných faktorov úspechu, a to na základe klastrovania obsahovo blízkych stimulov. Pri vlastnom kvantitatívnom spracovaní sme zlúčili prvé dva varianty odpovedí na hodnotiacej škále (podstatné + vel'mi dôležité), ktoré predstavujú vyhranenú mieru dôležitosti daného stimulu.

Identifikovali sme tak štyri typy možných subjektívnych preferencií, ktoré sme označili:

meritokratická orientácia preferencii (dôraz na vlastné úsilie a výkon) reprezentovali ju vyhranene pozitívne hodnotené skutočnosti: mat' dobré vzdelanie, byt' ctižiadostivý, usilovne pracovat', mat' odvahu ist' za prácou do zahraničia, ovládat' cudzie jazyky

preferencie na sociálny pôvod (rodinný kapitál) - reprezentovali ju vyhranene pozitívne hodnotené skutočnosti: pochádzat' z bohatej rodiny, mat' vzdelaných rodičov

atributivne preferencie (význam charakteristík, ktorých je respondent nositel'om) - reprezentovali ju vyhranene pozitívne hodnotené skutočnosti: byt' mužom/ženou, žit' v prosperujúcom regióne, byt' mladý

\footnotetext{
25 Využili sme disponibilné triedenia podl’a základných socio-demografických znakov, pohlavia, veku, vzdelania, sociálneho statusu (identifikovaného cez redukované kategórie ISCO kódovania), vel'kosti sídla a regionálnej príslušnosti respondentov.
} 
preferencia účelového sociálneho kapitálu - reprezentovali ju vyhranene pozitívne hodnotené skutočnosti: poznat' správnych l'udí, mat' politické konexie, dávat' úplatky.

Distribúcia identifikovaných 4 typov subjektívnych preferencií bola nasledovná: najviac preferovaná bola meritokratická orientácia $(28,6 \%)$, za ňou nasledovalo hodnotenie významu sociálneho pôvodu $(17,8 \%)$ a atributívne preferencie $(17,3 \%)$, najmenšiu preferenciu (ale pritom relatívne blízku predchádzajúcim) mal účelový sociálny kapitál $(12,8 \%)$.

Čo sa týka diferenciácie distribúcie orientácií, ukázali sa niektoré odlišnosti, ale nepotvrdili sa štatisticky významné rozdiely medzi kategóriami respondentov $^{26}$

Vyšší podiel tých, ktorí hodnotia pre dosiahnutie úspechu význam vlastného výkonu (meritokratický princíp), sa ukázal medzi mestským obyvatel'stvom ${ }^{27}$ a kategóriami, ktoré by sme mohli označit’ ako vyššiu strednú triedu ${ }^{28}$.

Pri testovaní preferencií rodinného kapitálu sa podl'a sociodemografických kategórií nepreukázali významné rozdiely, čo naznačuje všeobecne distribuovanú akceptáciu významu tohto fenoménu.

Atributívne charakteristiky sú zvýznamňované medzi obyvatel'mi z menších obcí (do 1000 obyvatel'ov), u d'alších sledovaných sociálnodemografických kategórií sú preferencie atributívnych charakteristík na úrovni priemeru celej vzorky.

Vyšší podiel takých, ktorí hodnotia pre dosiahnutie úspechu význam vplyvných známostí a dávania úplatkov, je medzi mužmi a príslušníkmi nižšej strednej, resp. nižších tried (remeselníci, operátori, montéri a kvalifikovaní pracovníci v pol’nohospodárstve, pomocní a nekvalifikovaní pracovníci).

Pozitívnym výsledkom testovania je dominancia vnímania meritokratických charakteristík ako klúčových pre životný úspech. Potvrdil sa tak trend posilňovania týchto charakteristík, ako aj rozsah distribúcie takýchto hodnotení. Hoci ide o subjektívne vnímanie, nepriamo možno identifikovat' pozitívne smerovanie spojenia životných šancí s vlastným výkonom a úsilím. Silnejšia je takáto inklinácia v hodnotení l'udí z mestského prostredia a vyšších sociálnych vrstiev. Na druhej strane práve l'udia s nižším sociálnym statusom a $\mathrm{z}$ vidieckeho prostredia častejšie interpretujú životné príležitosti podmienené vplyvnými známost’ami (možno hypoteticky interpretovat' ako subjektívny výraz vnímania určitej miery vlastnej sociálnej marginalizácie). Zvýznamňovanie „objektívnej“ determinácie životných šancí (atributívne preferencie) sa tiež skôr týka l'udí z vidieckeho prostredia a nižším sociálnym statusom.

\footnotetext{
${ }^{26} \mathrm{Na}$ štatistické testovanie sme využili znamienkový test, ktorý je založený na adjustovaných rezíduách v dvojrozmernom triedení znakov a vyjadruje štatistickú významnost' rozdielov premenných.

27 Vo výskumnej kategorizácii to boli obyvatelia miest s 20 - 100 tisíc obyvatel'mi.

${ }^{28}$ V ISCO kódovaní to boli zákonodarcovia, riadiaci pracovníci a špecialisti.
} 


\section{Záver}

Prezentované vybrané zistenia z medzinárodných výskumov sociálnych nerovností, realizovaných na Slovensku iste nemôžu poskytnút úplný obraz o životných šanciach obyvatel'ov Slovenska. Limit je nielen v neúplnosti (pri tak zložitom zábere možných vplývajúcich skutočností), ale aj v subjektívnom hodnotení vybraných aspektov životných šancí.

Zároveň však výsledky výskumov umožňujú formulovat' niektoré závery. Pokúsime sa aspoň rámcovo reflektovat' životné šance na pozadí nami konceptualizovaných spoločenských mechanizmov. Názory a hodnotenia respondentov dokladujú posun $\mathrm{k}$ meritokratickému usporiadaniu spoločnosti a posilňovaniu tejto tendencie. Otvorenost' životných šancí, založených na individuálnom úsilí a výkone, ale naráža aj v subjektívnom vnímaní na limity objektívneho dostatku príležitostí viazaných najmä na klúčovú platformu životných šancí dostatku pracovných príležitostí a ich rovnomernej distribúcie $\mathrm{v}$ regionálnom rozložení. Narastá aj vnímanie limitnosti uplatnenia sa v slovenských podmienkach, čo by malo byt' osobitnou výzvou pre posilňovanie férovosti spravovania slovenskej spoločnosti (téma efektívnosti formálnych kontrolných mechanizmov a spravodlivého uplatňovania zásad). Otvorenost' životných šancí je v subjektívnom hodnotení limitovaná práve bariérami prístupu založenými na vplyvných sociálnych siet’ach. Sociálny kapitál na Slovensku má viac individuálnu podobu a je skôr zdrojom nerovností v prístupe $\mathrm{k}$ životným príležitostiam a úspechu. Na druhej strane kolektívny sociálny kapitál, ktorý by mohol byt' spolutvorcom životných príležitostí l'udí v podobe samoorganizačného mechanizmu (žiaduceho najmä na lokálnej úrovni), má nízku úroveň ${ }^{29}$. Nízka úroveň dôvery medzi l'ud'mi oslabuje potenciál kooperativity a úroveň dôvery k inštitúciám (najmä verejným) preukazuje nepriamo na nízku úroveň efektivity fungovania verejného sektora a inštitucionálneho nastavenia slovenskej spoločnosti ${ }^{30}$.

Oproti rovnostárskemu modelu spoločenského usporiadania pred rokom 1989, prebieha v procese transformácie spoločnosti proces diferenciácie. L'ud'mi je ale hodnotený nepriaznivo - vel'kú čast' populácie podl'a ich hodnotenia tlačí na spodné priečky spoločnosti, zatial’ čo žiaduci obraz spolo-

\footnotetext{
${ }^{29}$ Nízku úroveň kolektívneho sociálneho kapitálu potvrdzujú aj najnovšie údaje z výskumu európskych hodnôt EVS 2017, kde pri porovnaní členstva v rôznych formách dobrovol’ných organizácií na Slovensku a v Českej republike sa ukazuje priepastný rozdiel. Na Slovensku nie je členom žiadnej dobrovol'nej organizácie až $74,8 \%$ opýtaných, zatial' čo v ČR len 13,6 \% opýtaných (zdroj: dátový súbor EVS 2017, Sociologický ústav SAV).

${ }^{30} \mathrm{~K}$ úrovni dôvery medzi l'ud'mi a k verejným inštitúciám a ich vývoju od začiatku 90. rokov po súčasnost', pozri bližšie výskumy dôvery vo vlnách európskeho výskumu hodnôt EVS, odkaz:

http://www.sociologia.sav.sk/cms/uploaded/2786 attach_EVS_2017_SR_TK_SU_SAV_181217.pdf.

Porovnanie výsledkov preukazuje, že hoci dochádza k istému nárastu všeobecnej dôvery medzi l'ud'mi, súčasne narastá sociálny odstup k iným sociálnym skupinám. Vývoj dôvery k verejným inštitúciám v SR preukazuje stagnujúci až klesajúci charakter.
} 
čenského usporiadania by mal byt' vzostup väčšiny do stredných vrstiev spoločnosti ${ }^{31}$. Hoci ide o subjektívny hodnotiaci pohl'ad, aj ten vypovedá minimálne o limitoch motivačného a mobilizačného potenciálu l'udí pri hl'adaní a napíñaní svojich životných ciel’ov.

Gabriela Lubelcová pôsobí ako profesorka na Katedre sociológie Filozofickej fakulty Univerzity Komenského. Pedagogicky sa venuje sociológii sociálnych problémov, sociálnej politike, kriminológii a problematike aktivizácie sociálnych aktérov. Výskumne sa orientuje na analýzu aktuálnych sociálnych problémov, stratégie intervenovania do sociálnych problémov a sociálne inovácie. V kriminológii sa zameriava na problematiku sociálnej podmienenosti kriminality a v tejto oblasti publikuje vo vedeckých a odborných časopisoch a zbornikoch z konferencií. V poslednom obdobi sa venovala téme sociálneho podnikania ako inovatívnej stratégii lokálneho rozvoja a problematike prekarizácie práce a jej rizik v socio-ekonomickom vývoji Slovenska.

Milan Zeman pôsobí ako odborný pracovník Sociologického ústavu SAV. Vo svojej výskumnej práci sa zameriava na kvantitativne metódy, štatistické spracovanie dát a sociologické skúmanie volného času, športu, životného štýlu, konzumného správania, použivanie informačných a komunikačných technológii. Publikuje vo vedeckých a odborných časopisoch, ako aj kapitoly v monografiách a zbornikoch. Dlhodobo sa podiel'a na riešeni viacerých výskumných projektov v rámci medzinárodných komparativnych výskumov ISSP a EVS.

LITERATÚRA

ALEXANDER, J. C., 1988: Action and its Environments: Toward a New Synthesis. New York: CU Press, 1988.

ALEXANDER, J. C., 1982: Theoretical Logic in Sociology. Vol. I. London: Routledge.

BAHNA, M. - DŽAMBAZOVIČ, R., 2010: Subjektívna identifikácia vlastnej pozície v stratifikačnom systéme slovenskej spoločnosti. Sociológia, roč. 42, č. 2, s. 87112.

BAHNA, M. - ZAGRAPAN, J., 2017: Názory občanov na korupciu a ich osobná skúsenost'. Bratislava: SÚ SAV (elektronický zdroj).

BOURDIEU, P., 1998: Teorie jednání. Praha: Karolinum.

BOURDIEU, P., 1984: Distinction: A Social Critique of the Judgement of Taste. Harvard: UP.

BUNČÁK, J. - DŽAMBAZOVIČ, R. - SOPÓCI, J., 2013: Vývoj sociálnej stratifikácie slovenskej spoločnosti $\mathrm{v}$ posledných dvoch desatročiach. In: Londák, M., 31 K identifikácii vlastnej pozície v stratifikačnom systéme bližšie Bahna - Džambazovič 2010, údaje k vývoju sociálnej
stratifikácie a mobility, porovnaj Džambazovič - Gerbery - Sopóci 2018, Džambazovič - Gerbery 2014 . 
Michálek, S. a kol.: 20 rokov samostatnej Slovenskej republiky. Jedinečnost’ a diskontinuita historického vývoja. Bratislava: VEDA SAV, s. 570-610.

DAHRENDORF, R., 1991: Moderný sociálny konflikt. Bratislava: Archa.

DAHRENDORF, R., 1988: The Modern Social Conflict. University of California Press: Berkeley and Los Angeles.

DAHRENDORF, R.,1979: Life Chances: Approaches to Social and Political Theory. London: Weidenfeld and Nicolson.

DŽAMBAZOVIČ, R., 2015: Názory verejnosti na korupciu: Je na Slovensku korupčná klíma? In: Šoltés, P. - Vörös, L. a kol.: Korupcia. Bratislava: VEDA SAV, s. 422459.

DŽAMBAZOVIČ, R. - GERBERY, D., 2014: Sociálno-ekonomické nerovnosti v zdraví: sociálno-ekonomický status ako determinant zdravia. Sociológia 46, 2, s. 194-217.

DŽAMBAZOVIČ, R. - GERBERY, D. - SOPÓCI, J., 2018: Sociálna stratifikácia a sociálna mobilita v slovenskej spoločnosti. Bratislava: Stimul.

GERBERY, D. - DŽAMBAZOVIČ, R., 2011: Inovatívne orientácie v sociálnej politike: perspektíva sociálnej inklúzie. Bratislava: UK.

GIDDENS, A., 1984. The Constitution of Society: Outline of the Theory of Structuration. Cambridge: Polity Press.

KATRŇÁK, T., 2005: Tř́íní analýza a sociální mobilita. Brno: Centrum pro studium demokracie a kultury.

LUBELCOVÁ, G., 2014: Kriminalita ako modalita sociálneho konania. Sociológia 24, č. 2, s. 167-193.

SKOVAJSA, M., 2013: Struktury významu. Kultura a jednání. Praha: Slon.

SCHENK, J., 2017: Explanačné modely v súčasnej analytickej sociológii. Bratislava: Stimul.

SOPÓCI, J., 2013: Moderná spoločnost' a sociálna zmena. Bratislava: Stimul.

SOPÓCI, J., 2014: K niektorým otázkam spoločenskej triedy a sociálneho statusu v slovenskej spoločnosti. Sociológia 46, č. 2, s. 146-167.

SOPÓCI, J., 2017: Sociálna stratifikácia a mobilita v sociologickej perspektíve. Bratislava: Stimul.

SOPÓCI, J. - DŽAMBAZOVIČ, R. - GERBERY, D., 2015: Zdravie a zdravotná starostlivost' na Slovensku - nerovnost' v zdraví. Bratislava: Stimul.

Sociologický ústav SAV. CSES a ISSP Slovensko 2016. [dátový súbor]. Slovenský archív sociálnych dát, 2017. SASD2016002. Verzia 1.0.

ŠUBRT, J., 2001: Postavy a problémy soudobé teoretické sociologie. Praha: ISV.

ŠUBRT, J. - BALON, J., 2010: Soudobá sociologická teorie. Praha: Grada.

WEBER, M., 1964: Wirtschaft und Gesellschaft. Koln: Opladen.

\section{WEBSTRÁNKY}

http://sasd.sav.sk/sk/

http://sasd.sav.sk/sk/data_katalog_abs.php?id=sasd_2016002

http://www.sociologia.sav.sk/cms/uploaded/2786_attach_EVS_2017_SR_TK_SU_SA

V_181217.pdf

http://sasd.sav.sk/sk/data_katalog_abs.php?id=sasd_1993001 